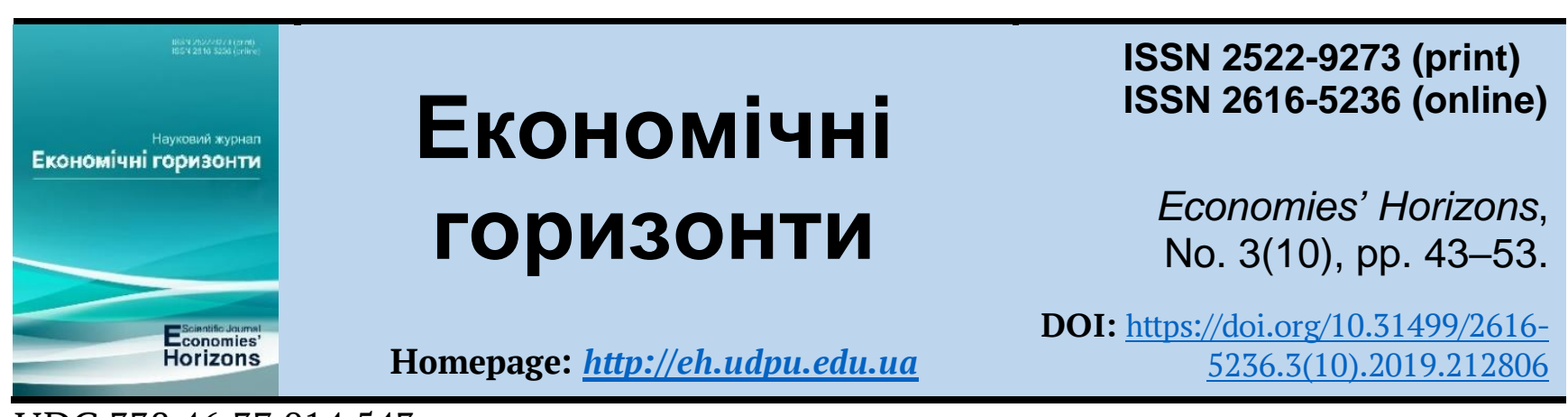

UDC 338.46:37.014.543

\title{
The system of maintaining the quality of education through public regulation of activity of higher education institutions
}

Received: 16 July 2019

Accepted: 20 August 2019
Nazariy M. Popadynets ${ }^{1}$, Cand. Ec. Sc. Yuliya V. Zhuravel ${ }^{2}$, Cand. Ec. Sc.

Olena V. Panukhnyk ${ }^{3}$, Doctor. Ec. Sc., Professor

Popadynets, M. M., Zhuravel, Yu. V., Panukhnyk, O. V. (2019), "The system of maintaining the quality of education through public regulation of activity of higher education institutions", Economies' Horizons, no.3(10), pp. 43-53, doi: https://doi.org/10.31499/2616-5236.3(10).2019.212806

Abstract. The purpose of the research is to determine government measures to form a mechanism to ensure the formation of the quality of education in higher education institutions. Methods. In the course of the research, general scientific methods and approaches, a systematic approach, general logical research methods (analysis, synthesis, generalization, comparison) were used. Results. The article discusses key studies of the development of education in the country; in particular, attention paid to the processes of state regulation of the activities of higher education institutions. On the basis of theoretical and methodological analysis, a general scheme of the mechanism of state regulation of higher education is proposed, which consists of subject-objective, target, instrumental and information-analytical components. It was determined that the stimulation of educational institutions to continuously improve the quality and availability of educational services in accordance with the future needs of the labor market and the economy, the production of new services occurs through partial regulation of these processes by the state. It has been proved that comprehensive legal, organizational, resource, information support for the development of the economy, employment and social infrastructure capable of realizing the rights of education and development of the population, as well as meeting the needs of various industries in qualified personnel, stimulating the demographic reproduction of the population directly depends on the quality of education in country, which is the basis for the formation of professional skills of each specialist. Practical meaning. Based on the analysis of the scientific works of domestic scientists, as well as the practice of one of the universities, a system of indicators and key measures of the external system for ensuring the quality of education have been determined. Most educational institutions in the country can use it by implementing in their practice those indicators to which this or that institution responds. Prospects for further research. The results obtained determine the need for further assessment of the impact of other indicators for the implementation of a comprehensive assessment of the internal and external system of education quality, which will help unify those indicators that will be most effective for a particular educational institution.

Keywords: education, quality of education, state regulation, mechanisms, competitiveness.

JEL Classification: I22.

\footnotetext{
${ }^{1}$ M. I. Dolishniy Institute of Regional Research of NAS of Ukraine; Senior Researcher of Department of Regional Economic Policy; ORCID ID: https://orcid.org/0000-0002-7556-6135; e-mail: popadynets.n@gmail.com

${ }^{2}$ Lviv State College of Food and Processing Industry of the National University of Food Technologies; Lecturer; ORCID ID: https://orcid.org/0000-0003-4065-540X; e-mail: jul zhur@ukr.net

3 Ternopil Ivan Puluj National Technical University, Head of the Department of Economics and Finance; ORCID ID: https://orcid.org/0000-0001-7381-6885; e-mail: panukhnyk@gmail.com
} 
Number of references: 19; number of tables: 1; number of figures: 1; number of formulas: $\mathbf{0 .}$

\title{
Система забезпечення якості освіти шляхом державного регулювання діяльності закладів вищої освіти
}

\author{
Назарій Миколайович Попадинець ${ }^{1}$, к. е. н. \\ Юлія Вікторівна Журавель ${ }^{2}$, к. е. н. \\ Олена Віталіївна Панухник ${ }^{3}$, д. е. н., професор
}

Стаття надійшла: 16.07.2019 Стаття прийнята: 20.08.2019
Popadynets N. M., Zhuravel Yu. V., Panukhnyk O. V. The system of maintaining the quality of education through public regulation of activity of higher education institutions. Економічні горизонти. 2019. № 3(10). C. 43-53. DOI: 26165236.3(10).2019.212806

Анотація. Мета статті є визначення державних заходів щодо формування механізму забезпечення формування якості освіти у закладах вищої освіти. Методи. В ході дослідження використано загальнонаукові методи та підходи, системний підхід, загальнологічні методи дослідження (аналіз, синтез, узагальнення, порівняння). Результати. У статті розглянуто ключові дослідження питань розвитку освіти в країні, зокрема звернута увага на процеси державного регулювання діяльності закладів вищої освіти. На основі теоретико-методологічного аналізу запропонована загальна схема механізму державного регулювання закладів вищої освіти, яка складається із суб'єктно-об'єктивної, цільової, інструментальної та інформаційно-аналітичної складових. Визначено, що стимулювання закладів освіти до неперервного покращення якості і доступності освітніх послуг відповідно до перспективних потреб ринку праці та економіки, продукування нових послуг відбувається шляхом часткового регулювання цих процесів державою. Доведено, що комплексне правове, організаційне, ресурсне, інформаційне забезпечення розвитку сфери економіки, зайнятості і соціальної інфраструктури, здатної реалізовувати права навчання і розвитку населення, а також задовольняти потреби різних галузей у кваліфікованих кадрах, стимулювати демографічне відтворення населення безпосередньо залежить від системи якості освіти в країні, що $є$ основою формування професійних навичок кожного спеціаліста. Практичне значення. На основі проведеного аналізу наукових праць вітчизняних науковців, а також практики одного з університетів визначено систему індикаторів та ключові заходи внутрішньої системи забезпечення якості освіти, яку можна використовувати більшістю закладів освіти в країні імплементувавши в свою практику ті індикатори, яким той чи інший заклад відповідає. Перспективи подальщих досліджень. Отримані результати визначають необхідність подальшої оцінки впливу інших індикаторів для здійснення комплексної оцінки внутрішньої та зовнішньої системи якості освіти що допоможе уніфікувати ті індикатори, які будуть найрезультативнішими для того чи іншого закладу освіти.

Ключові слова: освіта, якість освіти, державне регулювання, механізми, конкурентоспроможність.

Кількість джерел: 19; кількість таблиць: 1; кількість рисунків: 1; кількість формул: 0.

\section{Introduction.}

State regulation in the educational sphere is a complex management process that can be combined or concentrated on different directions, goals, objects. Today, state regulation, represented by state authorities, of the competitiveness of the activities of higher education institutions is a rather complicated process, since all institutions have great autonomy. However, it should understand that this is one aspect of management impact. For a comprehensive research of the mechanisms of the quality assurance system of

\footnotetext{
1 Інститут регіональних досліджень ім. М. І. Долішнього НАН України; старший науковий дослідник відділу регіональної економічної політики; ідентифікатор ORCID: https://orcid.org/0000-0002-7556-6135; e-mail: popadynets.n@gmail.com

2 Львівський державний коледж харчової і переробної промисловості Національного університету харчових технологіü; викладач; ідентифікатор ORCID: https://orcid.org/0000-0003-4065-540X; e-mail: jul zhur@ukr.net

${ }^{3}$ Тернопільський національний технічний університет імені Івана Пулюя; завідувач кафедри економіки та фінансів; ідентифікатор ORCID: https://orcid.org/0000-0001-7381-6885; e-mail: panukhnyk@gmail.com
} 
education through state regulation of the activities of higher education institutions, it is advisable to take into account vertical and horizontal instrumental relationships to achieve the set objective the identification of tools to ensure the competitiveness of higher education institutions.

\section{Literature review.}

A number of scientists are engaged in the issue of state regulation of education and the formation of a quality system for education in higher educational institutions in Ukraine. O. Hrynkevych in own research analyses the state regulation of competitiveness in Ukraine highlighting the main management components that are used for the process of the educational institution (Hrynkevych, 2016, pp. 87). O. Kuzmin and M. Yastrubsky analyse the education quality system in terms of normative legal acts and the possibilities of improving their competencies (Kuzmin and Yastrubskyy, 2017, pp. 66). T. Krystopchuk reveals one of the strategic goals of creating a single European higher education area - ensuring the quality of higher education (Krystopchuk, 2016, pp. 99-103). A. Rasco explores this issue in terms of standardization of the educational process, noting that it is a powerful neoliberal control tool in education, a way of subjectivizing teaching staff and the technology of domination and homogenization of educational practices (Rasco, 2020, pp. 263). In the work of P. Sahlberg, it notes that from the experience of many countries, the strengthening of the standardization of teaching and learning can lead to counterproductive expectations of increased economic competitiveness in the education system (Sahlberg, 2006, pp. 234). V. Viktorov's research based on such main components as contextual information, educational process, educational achievements, and resource contribution to education (Viktorov, 2005).

\section{Methodology.}

The research used general scientific methods and approaches, system approach, general research methods (analysis, synthesis, generalization and comparison).

\section{Research objectives.}

The objective of the article is to determine the state measures for the formation of a mechanism for ensuring the formation of the quality of education in higher education institutions.

\section{Results and discussions.}

In conditions of fierce competition among institutions of higher education, the issue of ensuring the quality of higher education has become extremely important. To provide quality services in the field of higher education, it is necessary to have sufficient material, technical, informational, human and scientific potential. At the same time, the presence of a large number of institutions of higher education, low in terms of educational and scientific potential, negatively affects the development of the quality of higher education.

The development of state and non-state higher education requires its state regulation, improvement of practical forms and methods of improving the quality of education and the development of scientific and theoretical foundations for increasing the efficiency of higher education management. The issues of state regulation of the sphere of higher education are of interest to both educators and economists, lawyers, political scientists, sociologists, civil servants and politicians. Therefore, today the meaning of "government regulation" viewed from a different angle and requires a more detailed analysis.

In particular, I. Kaleniuk, L. Tsymbal believe that this is a system of economic, social, legal, political and organizational forms and methods of influencing the subjects of the educational process, which determine the environment for the realization of their goals and at the same time meet both the strategic interests of the state and direct interests of the subjects of the educational process with resources (Kaleniuk and Tsymbal, 2011, pp. 69).

S. Krysiuk argues that it is advisable to influence the education system, carried out mainly by approving legislative acts, norms, establishing streamlining, improving general rules and norms of behaviour (Krysiuk, 2009, pp. 220).

For instance, Y. V. Kovbasiuk et al. consider the meaning of state regulation as the activity of the state (public authorities) aimed at creating conditions for the full implementation of the functions of the state, fundamental rights and freedoms of citizens, harmonization of various groups of interests in society and between state and society, provision of social development with appropriate resources (Kovbasiuk, et al., 2010, pp. 564). 
In turn T. Shestakovska, N. Kholiavko argue that this is a set of methods of direct and indirect influence of the state on the development of educational institutions using the instruments of legislative, administrative and economic regulation to ensure the conditions for its effective functioning. Their main opinion is that state regulation in the field of education should carried out in order to streamline the activities of educational institutions, ensure compliance with current legislation, and achieve the required level of quality of education, its compliance with the current needs of the national economy (Shestakovska and Kholiavko, 2016, pp. 33).

The regulatory documents also mention the importance of government regulation. Namely, The Economic Code of Ukraine determines that "the state for the implementation of economic policy, the implementation of targeted economic and other programs and programs of economic and social development uses a variety of means and mechanisms for regulating economic activity." Moreover, it is legally stipulated that the main means of regulating the influence of the state on the activities of business entities are: state order; licensing, patenting and quotas; technical regulation; application of standards and limits; regulation of prices and tariffs; provision of investment, tax and other benefits; provision of grants, compensations, targeted innovations and subsidies (The Verkhovna Rada of Ukraine, 2015).

Based on the provisions of the Law "On Higher Education", then "the formation and implementation of state policy in the field of higher education is ensured through the harmonious interaction of national education systems, science, business and the state in order to ensure sustainable socio-economic development of the state" (The Verkhovna Rada of Ukraine, 2014).
According
to
O. Kuzmin
and

M. Yastrubsky, central executive body in the field of education and science is the Ministry of Education and Science of Ukraine (MES), whose activities are directed and coordinated by the Cabinet of Ministers of Ukraine. The main tasks of the ministry include ensuring the formation and implementation of state policy in the spheres of education and science, scientific, scientific, technical and innovative activities, transfer (transfer) of technologies. As well as the implementation of state control over the activities of educational institutions, enterprises, institutions and organizations that provide services in the field of education or carrying out other activities related to the provision of such services, regardless of their subordination and form of ownership. Acts of the Ministry of Education and Science of Ukraine, within the limits of its authority, are obligatory for the ministries and departments to which educational institutions are subordinate (Kuzmin and Yastrubskyy, 2017, pp, 66).

I. Tsarenko defines the mechanism of state regulation of competitiveness at the level of higher education, laying in its goal the convergence of current measures and long-term goals with the provision of innovative and technological development of higher education and its compliance with the needs of the economy (Balabanova and Alacheva, 2003, pp. 25).

$\mathrm{N}$. Mischuk in the priorities of education development regulation lays down the provision of continuous reproduction processes in the industry, which, in turn, contribute to increasing the competitiveness of young people in the labor market (Mishchuk, 2019).

Y. Goryn, researching the management of the competitiveness of educational services, focuses on their advantages in terms of the degree of satisfaction of consumers' needs and the volume of costs, which directly reflects the competitiveness of an educational institution (Horyn, 2016). O. Hrynkevych actualizes in the management of competitiveness the ability of its providers to create products that provide advantages in the formation of intellectual capital and therefore in the implementation of the goals of individual and social development (Hrynkevych, 2018).

Interesting research on this topic is the work of A. Kobets, who notes, "when forming the foundations of the state regulatory mechanism, one should proceed from the fact that the market is the needs of today, and education lays the foundation for the country's long-term development. The main problem lies in the establishment of rational boundaries of state regulation in the context of the growing autonomy of the university, improvement of existing and development of new mechanisms of state regulation of higher education, adequate to modern trends in the development of the educational market”. According to the scientist, "the set of means, methods and techniques of systematic, consistent and scientifically grounded state regulatory influence on the higher 
education system that constitutes the method of state regulation" (Kobets, 2011).

Thus, the processes of state regulation in the educational sphere can cover:

1. Regulation of the educational sphere as a whole as a type of economic activity, a sphere of employment and a sphere of social infrared structure.

2. Regulation of the sphere of education as a center of scientific and innovative activity.

3. Regulation of educational institutions, including: are subjects of educational activity, i.e. (arts), doctor of sciences), specializations, forms (formal, informal, informal), have different legal status in terms of ownership and subordination, have different territorial affiliation (in different types of settlements); perform specific functions in the field of education - coordinating, controlling, consulting, patronizing; form and implement educational policy - international, state, regional, local, including those with signs of publicity.

4. Regulation of the parameters of educational activities - specialization, cost of services, organization of the educational process with the ratio of various types of activities (main pedagogical, scientific, innovative, artistic, educational, integration into the international educational space (educational mobility)), conditions of pedagogical and scientific activities (material-technical, financial, organizational, motivational). Also there are combinations/alternatives of real and online learning (functioning of mobile educational platforms), learning outcomes (success) (according to subjectobject assessments)), graduates 'competencies (in particular, according to employers' assessments), suitability to the employment of graduates (compliance of competencies with the needs and requirements of employers, career prospects in the chosen specialty (Rashkevych, 2014, pp. 69).

5 . Regulation of the quality indicators of the education sector - quality, competitiveness, innovation, practical value, inclusiveness, mobility (global accessibility), focus on comprehensive development, etc.

Taking into account all these studies, we can form a scheme of the mechanism of state regulation of all educational institutions, which forms the system of ensuring the quality of education (Figure 1).
Formulated in Figure 1 the objective of the state regulation mechanism of educational institutions changes the emphasis depending on their belonging to the educational level:

- institution of preschool education should ensure continuous improvement of the quality of educational services ensuring their accessibility physical (number of places, territorial proximity, inclusion with special needs) and financial. This is an urgent problem for many regions of Ukraine, especially large cities, where the load on free space in preschool education institutions reaches more than 5 people. This situation increases social tensions and encourages informal ways of gaining access to services;

- institution of general secondary education should ensure continuous improvement in the quality of educational services focused on the allround development of the child and provide him with basic opportunities to understand possible future professional specialization, based on personal abilities and preferences. Such an institution should have unconditional competitive advantages with strict adherence to regulated state standards, regardless of location, so that there are no differences in the quality of the provision of educational services between different types of settlements (metropolitan, urban, rural) and within one settlement (located in the central part of the settlement or on the periphery);

- institution of vocational (vocational and technical) education should ensure continuous improvement in the quality of educational services and be able to compete with institutions of higher education levels by ensuring high integration with the future needs of the labor market, high-quality practical training with systematic gaining experience in industrial conditions;

- institution of professional pre-higher and higher education should ensure continuous improvement of the quality of educational services that can compete in the global mobile space, provide a wide range of various educational services. In particular, it should ensure for business and the public (development of innovative projects), science (research activities), other educational institutions within the framework of ensuring the structural stability of the country's education system. 


\section{Subject-object component}

INSTITUTIONAL SUPPORT (subject of regulation): The Verkhovna Rada of Ukraine, The Cabinet of Ministers of Ukraine, The Ministry of Education and Science of Ukraine, The National Agency for Qualifications, The National Agency for Higher Education Quality Assurance, other central executive bodies and local selfgovernment bodies

EDUCATIONAL INSTITUTIONS (object of regulation): activities, services, interactions

Target component

PURPOSE: high competitiveness of educational institutions that provide a sufficient list, availability, quality of educational services and are able to compete in the mobile educational space and the mobile learning market, inclu ding globally and for the long term.

OBJECTIVES: formation of a competitive environment for the activities of educational institutions as a condition for the provision of quality services; ensuring the structural stability of educational institutions; control over compliance with regulated educational standards and requirements in accordance with the right of an educational institution to autonomy; ensuring the integration of educational services with the labor market and business (the ability of graduates to realize their capitalized human potential), as well as the scientific, social, cultural, political environment; promoting the mobility of educational services

Instrumental component

LEGAL MECHANISMS: Constitution of Ukraine, basic legislation on education, legislation in the field of scientific and technical activities, legislation in the field of competition and competitiveness, Higher Education Development Strategy for 2021-2031, National Youth Strategy until 2030, educational programs, programs for the development of social infrastructure and employment in regions and communities.

ADMINISTRATIVE MECHANISMS: licensing, certification, accreditation, standards (model educational programs, industry standards, etc.), qualifications frameworks, qualification requirements for teaching staff, standard staffing standards, state supervision (control) in the form of property checks and punishments, intolerance corruption and bribery.

BUDGETARY MECHANISMS: budgetary allocations (7\% of GDP), state and regional orders, financing of research projects, financing of infrastructure projects.

INANCIAL MECHANISMS: taxation, price regulation, lending.

INVESTMENT MECHANISMS: attraction of non-state financing, co-financing.

SOCIAL MECHANISMS: social protection of scientific and pedagogical personnel (additional guarantees, pension provision, scientific, teaching experience).

INSTITUTIONAL MECHANISMS: public-public administration and partnership, public-private partnership, cluster-cooperative interactions, international cooperation with the ratification of international law, international treaty regulation.

INFORMATION MECHANISMS: promotion of specialization, levels, educational institutions; positioning (branding) of domestic education on the world stage

Information and analytical component

Methodical recommendations for forecasting the development of education, determining the potential of educational institutions.

Monitoring the quality and competitiveness of educational services (sociological surveys).

Statistical accounting and financial reporting of educational institutions.

\section{Fig. 1. General scheme of the mechanism of state regulation of higher education}

Source: suggested by the authors.

The specificity of the mechanism system of state regulation on educational institutions is its integration with the mechanisms of regulation of the labor market and employment. Integration with the labor market is one of the foundations of the state policy in the field of education, regulated by the Law of Ukraine "On Education" (Official site of the Verkhovna Rada of Ukraine, 2014).

Note, the formation of the mechanism is necessary for the formation of the components of the education quality assurance system, which include: quality assurance system in educational institutions (internal system of education quality assurance); system of external assurance of the education quality; system of quality assurance in the activities of governing bodies and institutions that carry out external assurance of the quality of education.

Thus, the quality assurance system in educational institutions (internal system for ensuring 
the quality of education) may include: strategy (policy) and procedures for ensuring the quality of education; system and mechanisms for ensuring academic virtue; promulgated criteria, rules and procedures for evaluating education applicants; promulgated criteria, rules and procedures for assessing pedagogical (scientific and pedagogical) activities of pedagogical and scientificpedagogical workers; promulgated criteria, rules and procedures for assessing the management activities of the leading employees of the educational institution; ensuring the availability of the necessary resources for organizing the educational process, including for independent work of applicants for education; ensuring the availability of information systems for the effective management of an educational institution; creation of an inclusive educational environment in an educational institution, universal design and reasonable accommodation; other procedures and activities determined by special laws or documents of the educational institution.

It should note that the main strategic goal of the state educational policy in Ukraine is to ensure the quality of education. For this, the process of state regulation helps to form an effective system that can adequately respond to the challenges of the present and function stably. It consists of two closely related systems: internal and external, where the internal plays the main role, thanks to the development of an internal system for ensuring the quality of education and regular self-assessment, it is possible: to improve the quality of educational services and ensure confidence in learning outcomes; to receive constant feedback from the participants of the educational process on the quality of education, to respond in a timely manner to risks; to constantly improve the educational environment, the assessment system, scientific and pedagogical activities, management processes; to ensure the transparency of the school's activities and readiness for changes in the interests of the participants in the educational process.

To create an internal system is a strategic decision of any institution of higher education. It can help improve its overall effectiveness and provide a solid foundation for effective and sustainable development initiatives. The internal system is a tool that will allow the institution to develop, provide and adjust the processes of its educational activities.
An internal system is understood as a set of conditions, procedures and measures in an educational institution that ensure the effectiveness of educational and managerial processes that directly affect the quality of the educational process, the formation of key competencies of children of early and preschool age, contributing to the comprehensive development of the personality.

Today, the process of creating an internal system can be divided into two stages: theoretical - to define goals, resources, components and criteria, develop a local document, namely the Regulation on the internal system; practical - to conduct a self-assessment, determine the quality levels of educational activities and ways of improvement.

The model of the internal quality assurance system of education that you will create will depend on the duration of these stages and their components. Certainly, based on the unified models that we below propose.

The model will also depend on what answer you give yourself to the question: what does the internal system mean to you for the staff of the establishment? Is this a formality or an impetus to active, not always convenient decisions and actions? If this is an impetus for action, then plan: what, when, who and with the help of what will develop the internal system, will evaluate, analyse, etc. This will also affect the constituents of the model.

Which model of creating an internal system to choose, decides only the staff of the educational institution. It should also note that a properly formed system of education quality should be based on certain principles, namely: autonomy of a higher educational institution; awareness by all employees of the institution of responsibility for the quality of educational activities; recognition of the need to develop strategies, policies and procedures for quality assurance of an educational institution; making management decisions based on the analysis of timely, complete and objective information; continuous training of personnel; cooperation with all interested parties; continuous improvement of the quality of education, educational activities and the quality management system of education in the institution.

Compliance with these principles will allow 
the formation of the level of quality in the provision of educational services that will meet international standards and will provide the majority of domestic institutions with a high rating in international comparisons.

In addition, the observance of the presented principles allows forming the main objectives of the quality assurance system:

- definition and specification of the content of the quality control procedures in education;

- ensuring compliance with national licensing conditions for the provision of educational services, state, European and international educational standards;

- development and implementation in the educational process of normative documents on the quality of education;

- monitoring the resources of the educational process of the educational institution;

- analysis of the state of the information system in terms of its effectiveness for managing the educational process;

- monitoring of ensuring the publicity of information about educational programs, degrees of higher education and qualifications;

- development of recommendations for improving the quality of educational activities;

- distribution between the structural divisions of the educational institution of areas of responsibility in the functioning of the internal system for ensuring the quality of educational activities;

- introduction of a self-analysis mechanism as an integral component of sustainable development of an educational institution.

The main tasks of the tasks include:

- examination and current monitoring of educational programs;

- organizing and conducting marketingmonitoring and socio-psychological research of target groups of applicants, parents, students, teachers, graduates, employers;

- development and continuous improvement of information systems of the educational institution;

- ensuring the correlation of the tasks of the internal quality assurance system of an educational institution with the procedures for external quality assurance of higher education in Ukraine;

- ensuring the publicity of information about educational programs, degrees of higher education and qualifications;
- development of recommendations for improving the quality of educational activities;

- monitoring of the resource potential of an educational institution and its management, provision of advanced training for pedagogical, scientific and scientific-pedagogical workers.

According to the above goals and objectives, it is possible to generalize the structure and organization of internal quality assurance in education.

In particular, today there can be a diverse structure, depending on the organization of the work of each educational institution, which is a part of its autonomy.

Foreign experience also does not provide a unified vision of the structure; it differs in different educational institutions in different ways.

Coordination point can be a department, centre, commission (collegial elected body), and responsible persons.

The distribution of powers is possible both in the form of maximum concentration in one department or vice versa.

Moreover, it is worth emphasizing that the organization of internal quality assurance presupposes two foundations of the level:

- university;

- faculty.

The organization also provides for:

- current and long-term planning of work;

- development of proposals for monitoring activities to improve the internal system for ensuring the quality of education;

- coordination of the work of groups (sectors) to ensure the quality of education in institutes, faculties, departments;

- implementation of the latest educational technologies, information tools and technical means in the educational process and scientific activities;

- organization of work on the implementation of the policy of ensuring academic virtue;

- organization of the analysis of the quality of the teaching staff;

- organization of analysis and support of quality assurance processes in the departments of the educational institution;

- ensuring monitoring of the quality of educational activities by conducting and directly participating in the organization of surveys of applicants for higher education and teachers of the institute (faculty) on the quality of the organization 
of the educational process, graduates of the institute (faculty), representatives of the labor market.

A well-structured system of indicators and

key measures of the internal system for ensuring

\section{Table 1. System of indicators and key activities of the internal quality assurance system of education (according to ESG)}

\begin{tabular}{|l}
\hline \multicolumn{1}{|c|}{ INDICATORS } \\
\hline \multicolumn{1}{c}{ Formation of internal quality } \\
Availability and quality of internal normative legal documents governing the quality \\
assurance system, namely the provisions: \\
- on the assessment of work and determination of ratings of scientific, pedagogical \\
and scientific workers; \\
- on the official procedures for handling complaints and appeals of students; \\
- on the survey of students/teachers/graduates/employers; regulatory documents on \\
regulating the conclusion, making changes to training programs, involving inter- \\
ested stakeholders in this process; \\
- guidelines for working with documents related to the process of internal/external \\
quality assessment (including licensing and accreditation processes); \\
- a normative document regulating the measurement of the knowledge of students, \\
graduates, employers and teachers on the quality of the educational process; \\
\hline Separation of responsibilities between departments and officials to be involved in \\
quality assurance processes, as enshrined in the relevant normative and legal docu- \\
ments
\end{tabular}

The level of involvement of external stakeholders in quality assurance policy

The level of interest of students / teachers and employees of the educational institution in the regulation of procedures and ensuring the quality of the educational process (based on the results of surveys, feedback) the quality of education are gaining importance today in the context of the autonomy of educational institutions (Table 1).

\begin{tabular}{l|l}
\hline Activities of the Supervisory Board (decisions aimed at & improving the learning process) \\
implaphe
\end{tabular}

Compilation of the list of regulatory documents;

development of those documents that are lacking and bringing the existing documents into conformity with European standards; normalize the impact of a survey of internal and external stakeholders on educational and management processes

Compilation of the list of regulatory normative-legal documents; development of those documents that are missing and bringing them in line with existing European standards

Creation of joint councils with employers, where they discuss issues (decisions) of management and educational process.

Measures are aimed at increasing the level of interest students/teachers and employees of the educational institution in the regulation of procedures and ensuring the quality of the educational process; providing information on procedures and decisions in open access; prescribed mechanism for influencing decision-making and appealing

Develop rules of procedure of the Supervisory Board

\begin{tabular}{|c|c|}
\hline \multicolumn{2}{|c|}{ Development and approval of programs } \\
\hline $\begin{array}{l}\text { Document regulating the mechanism (procedure) for developing and approving ed- } \\
\text { ucational programs }\end{array}$ & $\begin{array}{l}\text { Development / approval of the mechanism (procedures) for the develop- } \\
\text { ment and approval of educational programs }\end{array}$ \\
\hline Professional group of educational program developers & $\begin{array}{l}\text { Clear requirements for the development team }+ \text { control over approved } \\
\text { programs by the licensing and accreditation department }\end{array}$ \\
\hline Number of new training programs & $\begin{array}{l}\text { Motivation of scientific and pedagogical workers (SPW) for the devel- } \\
\text { opment of new training programs }\end{array}$ \\
\hline $\begin{array}{l}\text { The level of involvement of employers in the conclusion and approval of programs } \\
\text { (number, percentage of each educational program) }\end{array}$ & $\begin{array}{l}\text { Motivation and development of an effective mechanism for involving } \\
\text { employers in the work on the conclusion of educational programs }\end{array}$ \\
\hline $\begin{array}{l}\text { The level of student involvement in the conclusion of programs (number, percentage } \\
\text { for each educational program) }\end{array}$ & $\begin{array}{l}\text { Development of an effective mechanism and motivation to involve stu- } \\
\text { dents in concluding programs }\end{array}$ \\
\hline Compliance of curricula with the goals and objectives of training & Concluding educational programs based on learning outcomes \\
\hline \multicolumn{2}{|c|}{ Student-centred learning, teaching and assessment } \\
\hline $\begin{array}{l}\text { Number of student surveys conducted on student satisfaction/dissatisfaction with } \\
\text { the quality of the educational process }\end{array}$ & $\begin{array}{l}\text { Conducting a systematic survey of students with the subsequent analysis } \\
\text { of the results (comparison of the results). }\end{array}$ \\
\hline $\begin{array}{l}\text { Number of students surveyed on student satisfaction/dissatisfaction with the educa- } \\
\text { tional process }\end{array}$ & The survey should display the full picture (cover the entire audience) \\
\hline $\begin{array}{l}\text { Availability of survey results and their impact on further changes (availability of } \\
\text { results in official documents, website) }\end{array}$ & $\begin{array}{l}\text { Description of the levels of access to the survey results, the scheme for } \\
\text { applying the results described. }\end{array}$ \\
\hline $\begin{array}{l}\text { Opportunity for dialogue between students and administration (the opportunity for } \\
\text { students to express their opinion / consideration of applications (complaints) of stu- } \\
\text { dents) }\end{array}$ & $\begin{array}{l}\text { Regular and systematic meetings of students and administration; conclu- } \\
\text { sion and publication of the procedure for consideration of appeals }\end{array}$ \\
\hline Academic mobility (the number of students who participated in the exchange) & $\begin{array}{l}\text { Concluding agreements with foreign partners, availability of infor- } \\
\text { mation, the procedure for crediting/transferring credits, support from the } \\
\text { administration and teachers }\end{array}$ \\
\hline $\begin{array}{l}\text { Involvement of students in the formation and implementation of educational policy } \\
\text { (the number of students in various commissions, collegial bodies, etc.) }\end{array}$ & Involvement of students in commissions, collegial bodies \\
\hline $\begin{array}{l}\text { Possibility of choosing academic disciplines (availability of software, disciplines of } \\
\text { FC (free choosing) }\end{array}$ & $\begin{array}{l}\text { Creating the possibility of a real choice of disciplines, reducing the lim- } \\
\text { iting framework when choosing disciplines, introducing an informal ed- } \\
\text { ucation in the educational process }\end{array}$ \\
\hline \multicolumn{2}{|c|}{ Enrollment, training, recognition of qualifications and certification of students } \\
\hline $\begin{array}{l}\text { Availability of mechanisms and procedures for enrollment, expulsion, renewal and } \\
\text { transfer of students of an educational institution (Regulation on the procedure for } \\
\text { enrollment, expulsion, renewal and transfer of students of an educational institution, } \\
\text { Regulation on the procedure for training specialists in specialties, Regulation on the } \\
\text { organization of the educational process, Regulation on the procedure for transferring } \\
\text { students to vacant places of the state order) }\end{array}$ & $\begin{array}{l}\text { Development of a regulation, bringing existing provisions in line with } \\
\text { European standards, updating the provisions }\end{array}$ \\
\hline
\end{tabular}


Table 1 continuation

\begin{tabular}{|l|l|}
\hline \multicolumn{1}{|c|}{ INDICATORS } & \multicolumn{1}{|c|}{} \\
\hline Involvement of external stakeholders in student assessment process & \\
\hline Employers' assessment of the professional qualifications of graduates (survey) & $\begin{array}{l}\text { Scientific achievements of students and student involvement in scientific work } \\
\text { (monitoring and polls) }\end{array}$ \\
\hline
\end{tabular}
ACTIVITIES

Inclusion of external stakeholders in the examination commissions; involvement of employers in the current process of student assessment

Conducting a survey of employers on the professional qualifications of graduates

Monitoring and evaluating students' scientific achievements

Availability of a list of clear competencies and requirements for the teacher when hiring and competitive selection to replace the positions of research and teaching staff of educational institutions (Requirements for teachers must be clearly defined in internal regulations: statute, collective agreement, Regulations on teacher rating, to fill vacancies in scientific and pedagogical workers, provisions ...)

Taking students' opinions into account when evaluating a teacher (survey)

Assessment of pedagogical (teaching) skills (evaluation by colleagues and external experts)

Procedures for re-certification of teachers (regulations)

Teacher training

Monitoring and evaluation of the teacher's scientific activity (Regulations on teacher rating)

International academic mobility of teachers (number of exchanges and internships) for exchanges)
Learning resources and student support

Access to library resources (staffing of the library, availability of specialized, faculty $\quad$ Increasing library holdings, providing access to online libraries (access

and departmental libraries)

Existing laboratories, centres, research institutes

E-learning system

Housing stock for students (number of dormitories)

Develop requirements for research and teaching staff (RTS), approve these requirements, adhere to the hiring and re-certification + control by the educational and methodical department (EMD) and the employment department

Develop a mechanism for obtaining and legitimizing data on teacher assessment by students; conduct surveys; take into account survey data

Development of mechanisms and methods of assessment, determination of the range of persons who can conduct such assessment; evaluation, use of results

Description and approval of the procedure; compliance with the procedure

Creating conditions for advanced training, practice of internships in the workplace, teaching didactic skills; teacher motivation procedures

Develop: Evaluation mechanisms, Regulations on teacher rating, teacher motivation; involvement of external stakeholders in the process of evaluating the scientific and pedagogical activities of the teacher Increase of agreements on foreign cooperation (expansion of the circle to international library pools), updating holdings

Upgrading equipment, providing adequate funding for full-fledged work Wider involvement of the system

Expansion of the housing stock, creation of proper living conditions in it Information management

\begin{tabular}{l|l} 
Information system for the management of an educational institution & Development of such a system, its implementation and maintenance
\end{tabular}

Participation of educational institutions in Ukrainian and international rankings of $\quad$ Develop and implement mechanisms for working with international universities (positions of educational institutions in rankings)

Public information rankings; mechanisms for improving positions

The presence on the official website of the university of the charter, licenses, certif- $\quad$ Submission and regular updating of such information; control over it icates of accreditation, information about structural divisions, reports on activities, etc.

Financial and administrative transparency of the university (availability of information on public procurement, management personnel, staffing table, etc.)

Information content of the teachers' page (presentation of information about courses, methodological literature, etc.)

Availability of an information package on the content of training in Ukrainian and foreign languages

Timely updating of information on the website of the educational institution, faculties, divisions

Availability of information in demand by stakeholders (about the employment of graduates, admission rules)

\section{Ongoing monitoring and periodic review of programs}

A documented procedure for current monitoring and periodic review of programs

Periodic measurements of knowledge, allowing to evaluate learning outcomes

Assessment by students of the quality of existing curricula (survey)

Employers' assessment of the quality of existing training programs (survey)

Involvement of employers in monitoring and reviewing programs (the number of employers included in the development groups)

Submission and regular updating of such information; control over it

Submission and regular updating of such information; control over it

Publish an information package on the content of education in Ukrainian and foreign languages; update information

Timely updating of information

Submit information and update it in time

Compilation of an appropriate regulatory document or making additions to an existing one (Regulations on the organization of the educational process)

Carrying out such measurements and analysis results

Develop a mechanism for such a survey, approve it by regulatory documents, put it into operation, analyse the results

Develop a mechanism for such a survey, approve it by regulatory documents, put it into operation, analyse the results

Develop a mechanism for involvement, approve it with regulations, put into effect

Cyclical external quality assurance

The place of educational institutions in international rankings

Develop mechanisms for inclusion in rankings and improvement of positions

Involvement of external stakeholders in educational advisory bodies

Develop a mechanism for involvement, approve it with regulations, put into effect

\section{Source: Ivan Franko National University of Lviv (2018).}

The presented indicators of the education quality system are proposed by one of the higher educational institutions of Ukraine. These indicators are the main ones for the internal system of

education quality. One can take them as a basis for other institutions of higher education in Ukraine and implemented into internal documents. 


\section{Conclusions.}

The main specific of the mechanism of state regulation of the education quality in higher educational institutions, in contrast to other object areas, is the primary use of tools that focused on improving the quality of educational services and countering violations of educational standards. Educational institutions, conducting joint research with government authorities, must understand global and local trends in economic and social development and provide for new competencies of consumers of educational services in educational programs.
The mechanism operation of state regulation of the education quality system in educational institutions is important for the achievement of other goals of the socio-economic and sustainable development of the state. In particular, measures in the field of education in general and in the activities of educational institutions, in particular, contribute to the improvement of labor results, which, in turn, reflected in the indicators of economic development. Therefore, in modern conditions of the knowledge society, the competitiveness of education is a factor in ensuring the competitiveness of the economy.

\section{References}

Balabanova, A. and Alacheva, T. (2003), Information support of management decisions in the context of the marketing orientation of the enterprise. Donetsk: DonSUET them. M. Tugan-Baranovsky, $143 \mathrm{p}$.

Horyn, Ya. O. (2016), "Management of competitiveness of educational services in the sphere of higher education of Ukraine”, Ph.D. in Econ. Dissertation, Lviv, Ukraine.

Hrynkevych, O. (2016), "Forecasting the Demand in the Educational Services Market in Ukraine (on the Example of Admission Volumes to Ukrainian Higher Educational Establishments)", Economic Journal of Lesya Ukrainka Volyn National University, no. 6(2), pp. 83-89.

Hrynkevych, O. S. (2018), "Management of competitiveness of higher education of Ukraine (methodology of analysis and monitoring system)", Dr.Sci. in Econ. Dissertation, Lviv, Ukraine.

Ivan Franko National University of Lviv (2018). "Internal quality system of assurance at the university: An attempt to unify the model”, available at: https://projects.Inu.edu.ua/quaere/wp-content/uploads/sites/6/2018/03/Пропозиціi-CВ3ЯВОIFNUL-draft-v1.pdf (Accessed 20 May 2019)

Kaleniuk, I. and Tsymbal, L. (2011), Features of regulation of the market of educational services. Chernihiv: ChDIEU, 184 p.

Kobets, A. (2011), "The role of the state in the functioning of the market of educational services", Public administration: improvement and development, no. 8, available at: http://www.dy.nayka.com.ua/?op=1\&z=308 (Accessed 20 May 2019)

Kovbasiuk, Yu., et al. (2010), Encyclopedic dictionary of public administration. Kyiv: NAPA, 820 p.

Krystopchuk, T. (2016), “The quality assurance of higher education system: foreign experience”, Continuing Professional Education: Theory and Practice (Series: Pedagogical Sciences), no. 3-4 (48-49), pp. 99-103.

Krysiuk, S. (2009), State management of education. Kyiv: NAPA, 220 p.

Kuzmin, O. and Yastrubskyy, M. (2017), "State regulation of university activities, its importance in ensuring the progressive development of higher education education”, Economic Journal of Odesa Polytechnic University, no. 1(1), pp. 64-69.

Mishchuk, N. V. (2019), "Organizational and economic regulation of education in the system of youth competitiveness in the labor market of Ukraine”, Ph.D. in Econ. Dissertation, Lviv, Ukraine.

Rashkevych, Yu. M. (2014), Bologna process and a new paradigm of higher education. Lviv: Lviv Polytechnic University, $168 \mathrm{p}$.

Rasco, A. (2020), “Standardization in education, a device of Neoliberalism”, Journal of Critical Education Policy Studies, no. 7, pp. 259-287.

Sahlberg, P. (2006), “Education Reform for Raising Economic Competitiveness”, Journal of Educational Change, no. 2(18), pp. 227-255.

Shestakovska, T. and Kholiavko, N. (2016), "State regulation of the education system in a market economy”, Scientific Bulletin of Kherson State University. Ser. Economic sciences, no. 16 (3), pp. 32-35.

The Verkhovna Rada of Ukraine (2014), “On Education” available at: https://zakon.rada.gov.ua/laws/show/1556-18\#Text (Accessed 20 May 2019).

The Verkhovna Rada of Ukraine (2015), “Economic Code of Ukraine of January” available at: https://zakon.rada.gov.ua/laws/show/436-15\#Text (Accessed 20 May 2019).

Viktorov, V. (2005). "International models of educational indicators of education quality", Multiverse: Philosophical Almanac, no. 49, available at: http://www.filosof.com.ua/Jornel/M 49/Viktorov.htm (Accessed 21 June 2019).

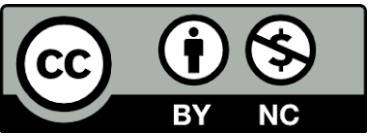

Цей твір ліцензовано на умовах Ліцензії Creative Commons «/з Зазначенням Авторства Некомериійна 4.0 Міжнародна» (CC BY-NC 4.0). This is an open access journal and all published articles are licensed under a Creative Commons "Attribution-NonCommercial 4.0 International" (CC BY-NC 4.0). 